\title{
Southern Partisan Changes: When and How*
}

Charles S. Bullock III, University of Georgia

Davison and Krassa (1991) are correct in their observations about the shifts in the partisan loyalties of southern blacks and whites over the last generation. Their suggestion that party lines may, in time, reinforce racial lines remains premature and cannot be substantiated by the time period of their analysis. It is possible, however, that by the beginning of the next century, the general thrust of their suggestions may have come to pass.

While Davison and Krassa and I (and a number of other analysts of southern politics, such as Carmines and Stimson 1989; Campbell, 1977) have come to similar conclusions about partisan realignment, we travel different paths. I am not convinced of the DavisonKrassa "white flight" explanation for the shift in partisan allegiance among white southerners. There are several factors that leave me doubtful.

\section{Time Order}

Davison and Krassa see whites fleeing to the GOP because of an increased black presence in the Democratic party. Blacks have come to constitute a larger share of Democratic voters in congressional elections, according to Davison and Krassa, as a result of the mobilization and shift in party allegiance of the black electorate. Survey research has shown that since 1964, southern black voters have overwhelmingly identified with the Democratic party and have supported its presidential nominees frequently at rates of 90 percent or better. Similar figures probably obtain for congressional elections. Davison and Krassa see the Voting Rights Act of 1965 as the stimulus for the larger black role in the Democratic party which, they claim, prompted whites to foresake the party of their ancestors. The authors choose to explore shifts in party voting in congressional elections on the rationale that since the Voting Rights Act (VRA) was approved by Congress, unhappy white southerners will direct their anger at Democratic congressional candidates.

*I appreciate the work of my research assistant Keith Gaddie who helped in the preparation of this article. 
For many southerners, partisan differences on civil rights became salient before enactment of the VRA. The 1964 presidential election which caused a critical realignment of blacks to the Democratic party (Campbell 1977) also resulted in unprecedented numbers of whites voting Republican in the states at the heart of Davison and Krassa's study. Barry Goldwater's opposition to the Civil Rights Act of 1964 produced a bumper crop of Republicans across the Deep South and established the pattern under which states covered by the VRA's trigger have voted Democratic in only one presidential election in the last seven elections. ${ }^{1}$ Goldwater's coattails elected the first Republican House members in Alabama, Georgia and Mississippi, and influenced the post-election switch of Albert Watson in South Carolina. North Carolina and Virginia had been electing Republicans to the House regularly since 1952 .

The Goldwater campaign is important to an understanding of white support for Republican congressional candidates for two reasons. First, the Goldwater candidacy inaugurated a series of presidential campaigns aimed at winning support among white southerners. Positions adopted by Republican presidential candidates pursuant to a southern strategy were also embraced by Republican congressional candidates.

Second, Goldwater's success in the Deep South, along with Nixon's victory in the Rim South in 1968 and his sweep of the South four years later, encouraged growing numbers of congressional aspirants to run as Republicans. After 1964, the number of congressional districts contested by the GOP increased substantially. As shown in Table 1, most districts in the covered states were not contested by the GOP in 1962. In subsequent elections, at least 70 percent of the districts had a Republican candidate. When there was not a Republican on the ballot, all voters who registered preferences voted for the Democratic candidate.

The shift to the GOP began before adoption of the VRA and while it may have been linked to issues of race, it is far from clear that the shift was a reaction to a growing black presence within the Democratic party. Certainly rejection of the Democratic party in congressional contests comes several elections after the VRA. Davison and Krassa's Figure 1 shows that the proportion of the white votes going to Democratic candidates was higher in both 1966 and 1970 than in any of the previous four off-year elections. Even as late as 1974, the Democratic share of the vote was in line with that tallied in off-year elections 
Southern Partisan Changes: When and How*

Table 1. U.S. House Districts Contested by Republicans in Off-Year Elections, 1962-1978

\begin{tabular}{|c|c|c|c|c|c|c|}
\hline & 1962 & 1966 & 1970 & 1974 & 1978 & $\begin{array}{l}\text { No. of } \\
\text { Districts }\end{array}$ \\
\hline Alabama & $*$ & 6 & 7 & 4 & 4 & $8 / 7 * *$ \\
\hline Georgia & 2 & 8 & 5 & 8 & 5 & 10 \\
\hline Louisiana & 2 & 3 & 2 & 4 & 6 & 8 \\
\hline Mississippi & 0 & 5 & 4 & 3 & 5 & 5 \\
\hline North Carolina & 8 & 9 & 10 & 8 & 10 & 11 \\
\hline South Carolina & 2 & 3 & 4 & 6 & 4 & 6 \\
\hline Virginia & 6 & 7 & 9 & 8 & 8 & 10 \\
\hline $\mathrm{N}$ & 20 & 41 & 41 & 41 & 42 & $58 / 57$ \\
\hline$\%$ & 40.0 & 70.7 & 70.7 & 71.9 & 73.7 & \\
\hline
\end{tabular}

*Alabama, which lost a seat after the 1960 census, did not redraw its districts in time for the 1962 elections. Candidates for Congress ran at-large with the eight leading vote getters winning nomination /election.

**Alabama went from eight to seven seats in 1972.

prior to the adoption of the VRA. A smaller share of the whites who voted may have backed Democrats after 1965, but Davison and Krassa do not provide the data needed to make that assessment.

With more GOP candidacies, it should be likely that Republicans attract larger shares of the white vote. Whites may have shifted to the GOP because of the availability of Republican candidates coupled with a preference for GOP issue stands over those of Democratic candidates. This alternative to white flight is not considered by Davison and Krassa.

\section{Ecological Fallacy}

Davison and Krassa seek to explore voting preferences of whites at three levels of education: high, medium and low. The estimates for these sets of whites are derived through ecological regression for different sets of counties. We have here a classic example of the ecological fallacy (Robinson 1950). The authors interpret their results as indicating levels of partisan support among whites having high, middle and low levels of education. Such inferences are not justified based upon analyses of the aggregate level data used when the county 
is the unit of analysis. The authors may be able to say something about the behavior of whites in counties having different levels of education. To say that whites in counties with higher levels of education vote in a particular way is not the same as saying that better educated whites support the Republican party at a certain level. The problem is that within each of the three strata of counties, there are whites spread across the continuum of education. With county-level data, we cannot know whether the GOP is drawing its support from whites who have high, middle, or low levels of education.

Even if we amend the authors' interpretations of Figures 2 and 3 to speak of white voting patterns in counties of differing levels of education, the Davison and Krassa interpretation is suspect. They seemingly concentrate primarily on Figure 3, which shows counties having lower levels of education surging to the top.

To determine the relative levels of GOP support for the three sets of counties, data from Figures 2 and 3 must be considered simultaneously. In Table 2 , I present data obtained by eyeballing the two figures. The numbers in the columns for Democratic and Republican support are based on what appear to be the data points in the figures and consequently may be slightly off. For each set of counties, a third column has been calculated to show Republican support as a percentage of Republican plus Democratic support. This table reveals that in each post-VRA contest, Republican candidates got greater support in counties having the highest education levels. Indeed, by 1978, counties with the least educated whites were also the counties in which Republican candidates fared least well.

To summarize, Davison and Krassa have not developed estimates of GOP support for whites having different levels of education. They present estimates of GOP support in counties having different levels of education. Second, contrary to the Davison and Krassa interpretation, the GOP has not done best in the least-educated counties.

\section{The Focus on the House}

As has been previously suggested, the rationale for focusing on the U.S. House is less than compelling. Deep South whites took first revenge on Lyndon Johnson who, as president, pushed through the Civil Rights Act of 1964. Southern whites' rejection of Democratic presidential nominees has been more persistent and pervasive than the rejection of Democratic congressional candidates. And why should 
Southern Partisan Changes: When and How*

Table 2. Estimates of Partisan Support By County, Controlling

for Educational Level

Education Level

Dem. $\frac{\text { Low }}{\text { Rep. } \% R e p ~ D e m . ~} \stackrel{\text { Medium }}{\text { Rep. \%Rep } \quad \text { Dem. }} \stackrel{\stackrel{\text { High }}{\text { Rep. }} \% \text { Rep. }}{\text {. }}$

\begin{tabular}{rrrrrrrrrr}
1962 & 19 & 6 & 24 & 20 & 12 & 38 & 16 & 15 & 48 \\
1966 & 24 & 17 & 41 & 25 & 15 & 38 & 19 & 16 & 46 \\
1970 & 23 & 16 & 41 & 23 & 14 & 38 & 18 & 15 & 45 \\
1974 & 19 & 15 & 44 & 18 & 10 & 36 & 15 & 13 & 46 \\
1978 & 14 & 12 & 46 & 12 & 14 & 54 & 11 & 14 & 56 \\
\hline
\end{tabular}

that not be the case? After all, only five of the Democrats from the seven states covered by Section 5 of the VRA voted for that legislation in 1965. No one from these states supported the 1964 Civil Rights Act. Legislators who opposed these bills were generally rewarded, although the anti-Johnson back lash was so strong that four Deep South opponents of the 1964 CRA fell. In 1966, two supporters of the VRA lost to Republicans, as did one opponent. These figures indicate that most opponents of the two statutes succeeded in convincing their constituents that they were distinguishable from the national Democratic party and, consequently, should not be punished as Johnson and Humphrey were in the Deep South.

\section{Split-Level Partisan Identification}

The last generation has seen the emergence of a number of voters who classify themselves as Georgia Democrats (Perkins and Guynes 1976) or Alabama Democrats (Cotter and Stovall 1986). This type of self-identification suggests that the voter will support his/her party's nominees for state and local offices while voting for the nominee of the opposing party for president. Charles Hadley (1985) discovered a number of split identifiers even among the political elites who attend party conventions. Others have since found that in at least some of the states studied by Davison and Krassa (Alabama, Arkansas, Kentucky), the proportion of split-identifiers is even higher in the general electorate than among party delegates (Cotter and Stovall 1986; Maggiotto and Wekkin 1987, 1989; Jewell 1987). As anticipated, 
such split-identifiers are less likely to vote for their party's presidential nominee than are those who experienced no cross-pressures (Hadley 1985; Wekkin 1991).

If the Davison-Krassa thesis of white flight from the Democratic party is correct, then their projections for partisan behavior should obtain at levels other than congressional elections. It would seem to follow that in counties that have sizable black populations, more whites should have abandoned the Democratic party than in counties in which there are fewer blacks. Of course, as noted earlier, for a GOP preference among whites to be visible, the opportunity to support Republican candidates must be present. If whites are rejecting the Democratic party then it would be reasonable for politically ambitious whites to run as Republicans. We hypothesize that the proportion black in the county will be positively related to the proportion of Republican candidacies and their success for local office, if the Davison-Krassa hypothesis is correct.

Table 3 presents data for South Carolina testing these hypotheses. South Carolina is chosen because it makes readily available general election data on county offices -- something not published for the other states subject to Section 5. The counties are divided into five categories based on the proportion black in the population in the 1970 census. We see that rather than Republican candidacies being more frequent in heavily black counties, just the opposite pattern exists. In 1974, almost a decade after the VRA, only 2 percent of the offices in majority black counties attracted Republicans while in the most heavily white counties, more than two-thirds of the offices featured Republican candidacies. GOP successes are rare in all categories of counties.

Local election data from South Carolina provide no support for the Davison-Krassa proposition that blacks are driving whites out of the Democratic party. Indeed, we suspect that the research done by Bullock (1988) showing that Republicans do best at the presidential level, and less well at lower levels, is an accurate portrayal. The level of Republicanism captured by Davison and Krassa is conditioned by the office considered. Had they looked at presidential elections, they would have observed more widespread Republicanism, but had their focus been on state or local offices, less GOP support would have been seen. White support for the GOP is, to a degree not acknowledged by Davison and Krassa, a reaction to the availability of Republican candidates and not due to blacks supporting Democrats. 
Southern Partisan Changes: When and How*

Table 3. Racial Composition of SC Counties and Incidence of GOP Candidacies for County Office, 1974

\begin{tabular}{ccccccc}
\hline & $\begin{array}{c}\text { GOP } \\
\text { Candidates }\end{array}$ & $\%$ & $\begin{array}{c}\text { GOP } \\
\text { Successes }\end{array}$ & $\%$ & $\begin{array}{c}\text { Nof } \\
\text { Offices }\end{array}$ & $\begin{array}{c}N \text { of } \\
\text { Counties }\end{array}$ \\
\hline$>50 \%$ black & 1 & $2.0 \%$ & 0 & $0 \%$ & 49 & $(12)$ \\
$40-49.9$ & 2 & 6.5 & 0 & 0 & 32 & $(7)$ \\
$30-39 / 9$ & 17 & 18.3 & 3 & 3.2 & 93 & $(13)$ \\
$20-29.9$ & 10 & 25.0 & 0 & 0 & 40 & $(8)$ \\
$<20$ & 26 & 68.4 & 3 & 7.9 & 38 & $(6)$ \\
\hline
\end{tabular}

\section{Is "White Flight" the Proper Analogy?}

"White flight" is a term often applied to racial transition in neighborhoods and schools. It connotes a rapid transformation from predominantly white to predominantly, or even almost universally, black. If speed and degree of change are hallmarks of white flight, then the concept is not well-adapted to the partisan change of Deep South whites.

Consensus does not exist among those who study party identification of southern whites. Some, such as Beck (1971), have concluded from the large numbers of independents that, rather than realigning with the GOP, southern whites have dealigned. Black and Black (1987) observe that the South lacks a majority party and, instead, has three minority groupings: Democrats, Republicans and Independents. Some more recent survey data suggest that more southern whites may profess allegiance to the GOP than to the Democratic party (Keene and Ladd 1991). Wolfinger and Hagen (1985), Carmines and Stimson (1989), and Campbell (1971) all see a realignment.

Whether realignment, dealignment, or a hybrid thereof, all observers agree that the changes in white allegiance and behavior have been so gradual that the former would have to be admitted at best a secular realignment (Key 1959). Figures on partisan officeholding in the South also show only a gradual increase in Republican success (Bullock 1988). Millions of whites in the South continue to vote Democratic, with Democrats continuing to dominate elections below the presidency.

Although whites are indeed foresaking the Democratic party, the rate of change is much slower than the term "flight" implies. 
Rather than leaving on a jet plane, the departure is more at the pace of a municipal bus. Indeed, declining Democratic identification may have relatively little to do with racial attitudes. After reviewing works on either side of the issue, Stanley and Castle (1988) conclude that survey research provides little evidence of a white backlash (also see Wolfinger and Hagen 1985). Other factors widely cited as predictive of partisan identification in the South, but not examined by Davison and Krassa, include generational replacement, in-migration and dissatisfaction with a wide array of Great Society programs.

Another source of greater liberalism within the Democratic party in the South has stemmed from the need for Democratic nominees to court black support. Democrats elected in recent years, particularly those competing statewide, have had to fashion biracial coalitions. This has resulted in most congressional southern Democrats voting for the 1982 extension of the VRA and against the confirmation of Robert Bork to serve on the Supreme Court, to cite two examples. Southern Republicans in Congress generally have been less supportive of civil rights and liberal programs (Bullock 1981; 1985; Nye and Bullock 1992). Currently, southern Democrats are feeling cross-pressured by the necessity of addressing minority concerns about recent Supreme Court rulings affecting employment practices, on the one hand, and by the fear that the GOP will run ads similar to the anti-affirmative action commercial used effectively by Jesse Helms (R-NC) in his 1990 reelection bid, on the other.

Still, the accumulation of white votes by Republicans comes slowly. Even in South Carolina, where the 1990 GOP ticket was headed by the legendary Strom Thurmond and where incumbent Republican Governor Carroll Campbell faced a weak black state senator, the GOP gained neither congressional nor state legislative seats. ${ }^{2}$

\section{The Future}

The GOP currently is seeking to tie the Democratic party more closely to blacks. Senator Phil Gramm's (R-TX) plans to link Democratic senators seeking re-election in 1992 with quotas for minority hiring is part of that effort. Where Democrats nominate blacks, the same message will be transmitted to some white voters. Also, the product of the current round of redistrictings may link blacks with the Democratic party in some voters' minds. The Justice Department interprets the VRA as requiring that states maximize majority black 
congressional and legislative districts which will likely produce additional black Democratic nominees. Some of these may occur in districts in which the minority population is sufficient to nominate a black but not sufficient to elect one, in which case a Republican wins. Elsewhere, the concentration of blacks in one district will likely result in neighboring districts having concentrations of conservative whites who will elect Republicans (Brace, Grofman and Handley 1987; Bullock and Gaddie 1991).

The factors associated with white drift toward the GOP are multiple and gradual. The ultimate result may be a predominantly black Democratic party and a predominantly white Republican party, if GOP strategists succeed. That scenario has yet to arrive at the congressional level, although it already describes presidential voting in the South.

\section{NOTES}

${ }^{1}$ Of the seven states covered by Section 5 of the 1965 VRA only Georgia and North Carolina have voted for the Democratic presidential nominee more than once, beginning with 1964 .

${ }^{2}$ The GOP did, however, win two statewide offices, secretary of state and superintendent of education, unseating an incumbent Democrat to take the former.

\section{REFERENCES}

Beck, Paul Allen. 1977. Partisan Dealignment in the Post-War South. American Political Science Review 71:477-496.

Black, Earl and Merle Black. 1987. Politics and Society in the South. Cambridge: Harvard University Press.

Brace, Kimball, Bernard Grofman and Lisa Handley. 1987. Does Redistricting Aimed to Help Blacks Necessarily Help Republicans? Journal of Politics 49: 169-185. Bullock, Charles S., III. 1981. Congressional Voting and the Mobilization of a Black Electorate in the South. Journal of Politics 43: 662-682.

. 1985. Congressional Roll Call Voting in a Two-Party South. Social Science Quarterly 66: 789-804.

. 1988. Regional Realignment: An Officeholding Perspective. Journal of Politics 50: 553-574.

and Ronald Keith Gaddie. 1991. Changing from Multi-Member to Single-Member Districts. Paper presented at the annual meeting of the Midwest Political Science Association, Chicago, IL. 